\title{
Non-Partisan School: A Conservative Education Initiative in Brazil
}

Contemporary Education Dialogue 19(I) 59-83, 202।

(C) 202I Education Dialogue Trust Reprints and permissions: in.sagepub.com/journals-permissions-india

DOI: I0.I I77/0973 I8492 II 053544 journals.sagepub.com/home/ced

(SAGE

\section{Álvaro Moreira Hypolito' (ID) and lana Gomes de Lima² ${ }^{2}$ (D)}

\begin{abstract}
The main goal of this article is to analyse the Non-Partisan School movement (EsP, or Escola sem Partido) which articulates social and political actors around a conservative agenda for education in Brazil. Based on Ball's studies, this article analyses political governance networks using a free software, GEPHI, using a qualitative network methodology. The article analyses some relevant social actors in this conservative initiative. The research shows that the Non-Partisan School, though presented as an initiative against ideological indoctrination, is in fact the result of a strong combination of ideological, conservative and partisan interests. The article shows that EsP is a conservative agenda among other movements in the struggle for ideological hegemony in the educational field.
\end{abstract}

\section{Keywords}

Non-Partisan School (EsP), political networks, governance, education

\footnotetext{
' Federal University of Pelotas, Brazil

${ }^{2}$ Federal University of Rio Grande do Sul, Porto Alegre, Brazil

\section{Corresponding author:}

Álvaro Moreira Hypolito, Federal University of Pelotas, R. Gomes Carneiro, n. I, PelotasRS, 96010-610, Brazil.

E-mail: hypolito@ufpel.edu.br
} 
Many of us are surprised that certain populist and conservative movements have been gaining social space and support from broad demographic sectors, as we have recently witnessed in Brazil. However, with the conservative government's promotion to and growth of homeschooling, as well as of numerous forms of state and non-state interference in the curricula and ways of teaching in public schools, scholars had already warned us about similar processes occurring in other parts of the world (Bordoli \& Conde, 2020; Löwy, 2015; Schirmer \& Apple, 2016; Severo \& Estrada, 2019). Michael Apple's critical analysis of conservative educational policies in the United States, especially his books Cultural Politics and Education (1996) and Educating the 'Right' Way: Markets, Standards, God and Inequality (2001) have been influential in shaping critical discourses in Brazil. Such policies are the result of what has been called 'Conservative Modernization' (Apple, 2001), which is the convergence of various interest groups, led by neoliberal lobbies. Some of Apple's arguments, particularly those concerning populist-authoritarian and neoconservative groups, have only recently become visible to scholars in Brazil.

In chapter three of the Apple's book Cultural Politics and Education (1996), there is a discussion of how parents' discontentment with certain school themes and the sometime hostile response of the school to parents could contingently lead to an extreme right-wing organisation such as Eagle Forum co-opting the opinions of parental groups towards a conservative agenda. As Apple (1996, p. 43) says,

These organizations often reach out to local groups of 'concerned citizens' and offer financial and legal assistance in their battles with school systems at state and local levels. Citizens for Excellence in Education, the Eagle Forum, the Western Center for Law and Religious Freedom, and Focus on the Family area among the most active.

In the example of Eagle Forum in Apple's book, a model letter would be constructed and presented by parents to the school councils in order to prevent the school from teaching their children content related to certain themes indicated in this letter, as well as methodologies considered dangerous, such as psychodrama (Apple, 1996, pp. 89-91). In Brazil, we can consider the Non-Partisan School movement (EsP, in Portuguese: Escola sem Partido) ${ }^{1}$ as a similar example. The EsP was created in 2004 and emerged in the 2010 in alliance with the conservative right-wing response to progressive reforms in schools as well as wider society introduced by policies of the social democrat/left-wing alliance that 
ruled the country from 2000. The introduction of progressive gender and sexuality programmes and the teaching of histories of radical movements in Latin America, generally, and Brazil, in particular, were the focus of the EsP's protests and mobilisations. Feminist organisations within the broad coalition under which the Partido dos Trabalhadores, Workers' Party (PT) ruled, influenced its policies and the EsP focused their attention on several of these policies, chiefly the promotion of women's reproductive rights. Through the creation of specific legislation, EsP uses a range of strategies to influence parents and teachers instead of pressurising each school directly (although parents are still encouraged to report and to act). In any case, it is a similar form of influence on the methodology of the schools, and on the content of what should or should not be taught, especially in public schools.

We seek to understand the EsP, like many other current political movements, through a theoretical lens that allows for more complex analyses of its structures and propositions. Thus, we make use of the concept of conservative alliance (Apple, 1996, 2001), also known in the literature as the New Right (Afonso, 1998; Apple, 1996, 2001; Clarke \& Newman, 1997). According to Apple (1996), four groups form this alliance. The first group is composed of the neoliberals, who lead the New Right and represent the group that is concerned with the politicaleconomic orientation linked to the notion of market. The second group of the alliance is the neoconservatives, who define the values of the past as better than the current ones and fight for cultural traditions. The third group consists of populist-authoritarians and is formed, in general, by members of the middle and the working class, who distrust the State and are concerned with security, family, knowledge and traditional values, and in particular, in the US context, the Jewish-Christian ones. Finally, the fourth group is made up of the new professional middle class and is concerned with social mobility. This segment 'may not totally agree with these other groups, but their own professional interests and advancements depend on the expanded use of accountability, efficiency and management procedures that are their own cultural capital' (Apple, 1996, p. 32). The concept of a conservative alliance aids in the understanding that there are articulations between different groups which may present, at many points, contradictory objectives between each other. Nonetheless, such groups are allied with common objectives, affording some concessions so that this alliance is consolidated. It is important to bear in mind that the articulations between these groups are not guaranteed for an indefinite period, as they are constantly being strengthened and renewed, and may, under certain circumstances, disappear, leading to the dissolution of 
previous bonds and new connections and rearticulations (Hall, 2009). Although articulations can occur between different practices and ideologies, such as in the conservative alliance itself, this does not mean that such practices become identical or that one dissolves the other: each remains with its different determinations and conditions of existence (Hall, 2009).

The socialist theorist Michael Harrington coined the term neoconservatism, referring to a new type of conservatism, that departed in some ways from principles similar to neoliberal ones. Neoconservatives, '[...] inspired by classical liberalism, believe that government interference in the economy and social programmes generated inflation, indebtedness and losses to productivity' (Moll, 2015, p. 56). Neoconservatism is born from an intellectual movement, in which principles of previous conservative currents are rescued, mainly from the old conservatism and libertarianism. What emerges as 'new' is due to the 'unusual fusion of these very different currents' (Moll, 2010, p. 67). According to Moll (2010, p. 67),

Libertarians understand that the world's problem is the lack of individual freedom, while old conservatives argue that totalitarianism is the result of an excess of individualism. For libertarians, individuals are the only ones who can set their own goals, while for old conservatives, setting any goal requires acceptance of beliefs and social ties. The two positions also differ on the notion of society. For libertarians, society is a contractual relationship between individuals that can be undone and has nothing transcendent to guarantee it, while old conservatives believe that society is a community that shares a series of common moral values and institutions that bind individuals each other. Above all, from an economic point of view, libertarians defended the virtues of capitalism based on a free market, but for the old conservatives this represented precisely the degeneration of traditional capitalism.

Even with such different assumptions, neoconservatism emerges from these two conservative currents. The main novelty of neoconservatism in contrast to the old conservatism is the incorporation of libertarian ideas, albeit within a neoliberal approach, focusing on the individual and the free economy. Therefore, at the same time that neoconservatives incorporate the principles of the old conservatives - affirming the centrality of society as a place of beliefs and social ties, based on a series of common moral values - they also defend a focus on the individual and the ability of this individual to exercise choice in the market economy. It should be noted that, although old conservatives and 
neoconservatives diverged in several aspects - the former criticised the latter for their little concern with principles and traditions, neoconservatives did not accept the prevalence of moral tradition, nor the rejection of modernity, aspects defended by the old conservativesboth groups ' $[\ldots]$ nurtured an anti-revolutionary feeling and opposed the countercultural movements and liberal social programmes of the 1960s' (Moll, 2010, p. 68).

Moll also identifies a religious and moral neoconservatism - close to what Apple (2001) calls authoritarian populism - that in Brazil expanded mainly through conservative evangelical churches, when evangelicals started to use the media to spread their ideas and defend effective political participation in the 1970s (Moll, 2010). Political participation was translated into denouncing communism and what was considered by these groups as a communist conspiracy in schools and government programmes.

In the context of Brazil, Lacerda (2019) understands that there is a close relationship between the Brazilian experience and US conservatism, including interference from US movements in different political spheres of Brazilian society. Lacerda (2019) sees the new Brazilian conservatism as a re-elaboration of the US neoconservatism of the 1970s and 1980s. Lacerda reconstructs the historical path, conceptual elements and political agents of US neoconservative thought, to then discuss its Brazilian manifestation, which would be currently taking place in similar fashion. An example of this relationship is the evangelical missions sent by Ronald Reagan during the period of the military dictatorship in Brazil. Such missions were important to disseminate churches, radio programmes and, thus, evangelical principles in the Brazilian context. In this sense, an important part of conservatism is currently made up of members of this church, who even comprise what is called the evangelical bench in the Federal Chamber of Deputies. Another example is that movements central to the current Brazilian conservatism receive funding from US right-wing institutions, such as Students for Liberty (Casimiro, 2018; Lacerda, 2019). Lacerda argues that, in Brazil too, the central pillar of the new conservatism is the Christian Right specially its affiliated evangelical groups which propose the defence of the 'traditional family' as a response to any diagnosis of social anomaly.

This article does not intend to analyse how this conservative alliance was formed in Brazil, but how a section of it is aligned to the interests of populist-authoritarian and neoconservative groups, namely the NonPartisan School movement (EsP). Our interest is to better understand how the EsP was formed from a political network of social actors. To this 
end, we initially present a brief history of the movement, pointing out how strong this organisation has become in terms of influencing educational policies in recent years. Following that, we present the methodology used in the research, which resulted in the elaboration of the network found in this article. Finally, we analyse this network to highlight some of the actors that compose the EsP and the importance they have had in the recent Brazilian educational scenario.

\section{The EsP: A Brief History}

The website of the movement Non-Partisan School (EsP) states that it is 'a joint initiative of students and parents concerned with the degree of political-ideological "contamination" of Brazilian schools, at all levels: from basic to higher education'. ${ }^{2}$ Furthermore, they claim that the EsP is 'an informal, independent, non-profit association without any kind of political, ideological or partisan ties'. Their goal is to impede 'an organized army of militants dressed as teachers [who] take advantage of the freedom of professorships and the curtain of secrecy of the classrooms to impose upon them their own worldview'. ${ }^{2}$ This movement was founded in 2004 by lawyer Miguel Nagib. According to Nagib, ${ }^{3}$ the idea for the EsP came up after a class in which his daughter's teacher compared Che Guevara to St. Francis Assisi. Since this was not a single episode, Nagib decided to lead the movement in an attempt to document similar situations, since according to him, people were unaware of such occurrences.

In 2014, Nagib was invited by state congressman Flávio Bolsonaro from Rio de Janeiro to draft a bill against indoctrination in schools to be presented to the Legislative Assembly. This came as an opportunity for Nagib who saw the potential of the draft bill to be promoted by congress members through the country. ${ }^{4}$

Nagib's bill intended to make mandatory the posting, in all elementary and high school classrooms, of a poster listing the duties of the teacher. These included the following: (a) the teacher will not take advantage of the students as captive audience to promote their own ideological, religious, moral, political and party interests, opinions or preferences; (b) the teacher will not carry out political party propaganda in the classroom or encourage his/her students to participate in demonstrations, public events and marches; and (c) the teacher will respect the right of students' parents to have their children receive a religious and moral education that is in accordance with their own convictions. ${ }^{5}$ 
In an analysis of the EsP programme and its proposed bill, Penna (2017) states that there is a delegitimisation of the teacher. The movement proposes changing the articles present in the Brazilian Federal Constitution regarding education, removing educational principles such as the pluralism of ideas and pedagogical concepts, as well as the freedom to teach. It is important to note that EsP does not propose a curriculum or a pedagogy. The movement only states that political and controversial issues should not be dealt with by teachers in the classroom. EsP's ideas are spread especially through social networks, and through complaints of teachers who do 'inappropriate practices' in the classroom, according to the movement. As for EsP funding, there is no transparent information on this issue in Brazil.

It is significant that EsP particularly targets public schools, which account for $81.4 \%$ of student enrolment. This is a clear threat to the democratisation of schooling in Brazil, a long and hard-won struggle since the end of the military dictatorship in 1985. There has been an increasing number of poor and black communities accessing schools in Brazil and the suppression of teaching in such schools only acts to disenfranchise them.

The EsP initially had the threat of ideological indoctrination as its principal agenda. On the website of the movement itself, knowing what happens inside a classroom is described as one of the objectives of the organisation. However, according to Luís Felipe Miguel (2016, pp. 595-596),

The growing importance of MESP [the author uses the acronym MESP to refer to the Non-Partisan School Movement] in the public debate occurs when its project converges with that of another aspect of the conservative agenda: the fight against the so-called 'gender ideology'. Before that, the idea of a 'Non-Partisan School' focused mainly on the fear of 'Marxist indoctrination,' something that had been around since the period of the military dictatorship. The fear of discussing gender roles grew with initiatives to combat homophobia and sexism in schools and was given priority by conservative religious groups. When merging it with its original agenda, MESP transferred the discussion to an apparently 'moral' terrain (as opposed to 'political') and started to frame it in terms of a dispute between schooling and family authority over children.

In this brief analysis of the actions supported or carried out by the EsP, it is clear that its interests are in targeting what they identify as political/ ideological indoctrination and promotion of progressive gender ideologies in schools. In the network diagram presented in Figure 1, the 


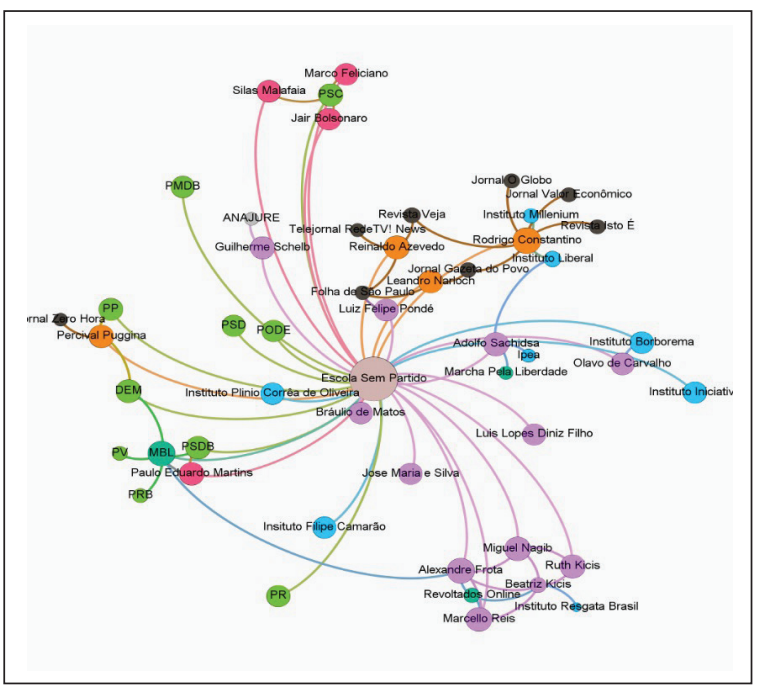

Figure I. Journalists

Media

Institutes
Politicians

Political Parties

Public Figures
Associations

Political Movements

Non-Partisan School

visualisation of the social actors involved in the EsP network undoubtedly shows, with greater or lesser intensity, that the network consists of actors who identify with conservative values.

\section{Methodology}

The first observation to be made is about our conception of state, educational policies and how neoliberal and conservative policies have been constructed in recent years, especially with regard to the educational field. Apple's Cultural Politics and Education (1996) had provided forewarning about these movements and articulations between neoliberal and neoconservative positions and how conservative movements can utilise legitimate local movements in order to strengthen their agenda. The Conservative Modernisation articulation analysed by Apple (1996, 2001) varies in both its coherency and in the defence of its propositions. Movements like that often defend proposals that are very diverse but 
articulate in favour of a class and cultural hegemony that privileges political domination, hegemonised by specific groups such as the neoliberals in recent decades. However, this does not hinder neoconservative initiatives such as those described by Apple as well as the EsP movement, which, in our understanding, have characteristics of neoconservative, populist-authoritarian and neoliberal groups.

In this context, we understand that education policies within any nation-state are now global policies, built on transnational networks. It is no longer possible to understand the state and its policies through methodological nationalism (Dale, 2005). In the last decades of the previous century and in the early years of the present one, we have witnessed important changes in the ways policies have come to be influenced and determined. Rather than being transferred in terms of power differentials, they have actually become a process of policy mobility based on a view of the state as a political governance network which migrates from a concept of government to governance or, better still, to a political network of governance (Ball \& Thawer, 2018; Nambissan \& Ball, 2010). Such a vision argues that there is a shift from a state form based on administrative, bureaucratic and hierarchical organisation to new spaces of governance - reflexive, self-regulated and horizontal-heterarchical.

The very notion of governance is now considered to be transnational in scope, where global political models influence normative power actions at a distance. In this sense, different sources, websites and social actors become widespread, and global networks of social actors (human and non-human, NGOs, consulting agencies, think tanks, and so on) influence global and local policies, articulating neoliberal and neoconservative interests (Ball, 2008, 2009, 2016; Ball \& Thawer, 2018; Nambissan \& Ball, 2010).

These new power regimes are also related to what Ball (2011) conceives as governance networks. Ball states that governance ' $[\ldots]$ is based upon network relations within and across new policy communities, designed to generate new governing capacity and enhance legitimacy' (2011, pp. 179-180). Thus, these networks bring new actors to the scene in relation to political processes, validating new discourses on policies and allowing new forms of influence and experiences, while at the same time incapacitating or depriving some previously established political actors of their rights. An important insight is that governance networks do not imply that the state has abandoned its ability to conduct politics: what comes into existence is 'a new modality of state power, agency and social action and indeed a new form of state' (Ball, 2011, p. 180). 
According to the Ball (2011, p. 181), these networks open space for new types of policy debate. Many of these debates, depending on the actors that make up these networks, 'embody and disseminate narratives of enterprise and enterprising solutions to social and educational problems', which, in turn, have to do with assumptions about the management of education.

The processes of globalisation have also been studied by Roger Dale (2000, 2005). According to Dale, one of the effects of these processes is that the state has been configured in a new way, even featuring another role, which he calls the 'Coordinating State'. New actors have emerged, and it is evident that educational policies are not only being formulated by state actors but also by those from other spheres (such as publicprivate partnerships, in which one of the agents is part of the non-state sphere). Thus, tasks and services that were previously the responsibility of the state are now performed by non-state actors (Ball, 2011; Dale, 2005). There is, therefore, an understanding that the concept of governance - as detailed above - is fundamental to the understanding of what has been happening within the policy framework. Ball (2012, p. 29) states that political networks "are the new manner of being "social", involving particular kinds of social relationships, flows and movements'.

In order to develop our study based on this conception, we utilise the network ethnography approach, a methodology that has been developed in several countries based on the need to better capture these new social actors (Ball, 2016; Ball \& Thawer, 2018; Howard, 2002). This methodological approach enables us to better understand groups which are hostile to a more fruitful dialogue, allowing for their investigation in order to understand in greater depth their principles and visions for education.

According to Ball, network ethnography is 'a mapping of the form and content of political relations in a particular field' (2012, p. 28). Howard (2002) states that network ethnography differs from an analysis of social networks as the latter fails to capture details about relationships that are not commensurable but are significant. Thus, network ethnography attempts to address this issue, making use of new forms of virtual and digital communication, which 'offer a broader and richer access to the "social" in social networks than has been the case using only terrestrial data' (Ball, 2012, p. 28).

Ball (2012, p. 28) further points out that network ethnography is related to 'a broad set of epistemological and ontological shifts across political science, sociology and social geography which involves a lessening of interest in social structures, and an increasing emphasis on flows and mobilities [...]'. These become significant given the emergence 
of the phenomenon of data dissemination through social networks. In Brazil, for example, we see the significant presence of the Internet in constructing a new sphere of political debate. According to Silveira (2015, p. 224),

The public sphere in which the various public opinions are formed can no longer be understood without observing the dynamics of the Internet, in particular the online social networks. In 2012, a survey on the Internet in Brazil conducted by the Internet Managing Committee showed that $74 \%$ of Brazilians used online social networks. Among all those in which political debates occur, the data indicated that Facebook was the most engaging space. Compared to churches, schools, unions, associations and political party headquarters, Facebook stands out as a communicative terrain which incorporates the most people with the most debates and political clashes.

Network ethnography used by Ball (2012) and others is applied in the mapping of the EsP network presented in the next section. Internet searches and the website and Facebook page of the Non-Partisan School (EsP) programme made possible a listing of people and institutions that are part of this organisation. From this initial mapping, other pages, sites and documents on the Internet were investigated, identifying actors who relate to these people and institutions identified on the site and the EsP page. Next, data was organised into different tables to better identify its main actors. Further mapping was carried out in order to identify the existing relationships between the identified actors. Finally, a network diagram was prepared to point out the actors and their relationships. The network was created using the software Gephi, ${ }^{6}$ which works with data generated from Internet collections or introduced into the software system itself to generate maps which enable us to identify nodes (social actors) by their size (designating their magnitude in the network) and their colours (which allow us to differentiate and group them by specific characteristics), and also according to the edges (which allow us to see relationships established between the nodes) that are interconnecting. The graphs can be interpreted in such a way as to understand that the greater the connections, the greater the relationships established in the network. The larger the circles (nodes), the greater the relevance of the social actor in the network and the lines (edges) indicate the relationships established, without defining, in the specific case of this study, the intensity of relationships or directionality. ${ }^{7}$ 


\section{The EsP Network}

Based on the methodological approach mentioned above, we have developed the network as shown in Figure 1. The purpose of this network is to identify some of the actors that take part in this organisation. The purpose of identifying these actors was as follows: (a) to understand some of the origins of the EsP; and (b) to provide some empirically grounded critique of the idea that the EsP does not have any kind of political, ideological or partisan links.

Before we begin the analysis of the network, it is important to note that it was prepared at the end of 2017, with minor updates in 2018. Thus, the network represents a 'snapshot' of a specific historical moment in which some actors played significant roles. It is likely that a later iteration of such a network will need to incorporate other/newer actors. However, it is reasonable to assume that the network explored here helps to understand an important moment in the history of the EsP, one that is significant for future studies that may complement this discussion.

A core objective in analysing the network was to understand who the actors are that make up the EsP and from which position they speak. Thus, it is understood that some of the premises that underpin the EsP can be demystified, as is the case with a non-ideological and non-partisan movement. We have not been able to discuss all actors in this article but have highlighted those who are key to EsP's functioning.

The EsP programme has been largely spread by what, in this network, we call public figures (nodes in purple). Such figures have become public, especially through social networks, which are also widely used to spread the ideas of the EsP. According to Silveira (2015, p. 223), 'the internet has consolidated itself as a space for political dispute and as a mobilization platform'. Silveira's work shows that social media in Brazil has played an active role in creating a certain common sense that has promoted right-wing politics, which the left has not been able to adequately engage with and dispute.

Social networks are currently a new locus for the study of political and social dynamics. Such networks have fostered the emergence and, in other cases, the consolidation of people and groups as influencers and shapers of public opinion. This is the case of the nodes that are at the bottom right of the EsP network, in which there is a small nucleus formed mainly by those referred to as 'public figures'. The fact that 
their names are grouped shows that they are closely related to each other. Among the public figures are Miguel Nagib, Ruth Kicis, Beatriz Kicis, Marcello Reis and Alexandre Frota. A brief overview of these subjects is provided below.

\section{The 'Public Figures' and Organisations Behind EsP}

As mentioned earlier, Miguel Nagib, a lawyer and attorney for the State of São Paulo, is the founder of EsP. According to Peroni et al. (2017), Miguel manages both the Non-Partisan School Training and Improvement Escola sem Partido Treinamento e Aperfeiçoamento ${ }^{8}$ (EIRELI) - whose main activity is related to training in professional and managerial development - and the Non-Partisan School Association Associação Escola sem Partido, ${ }^{9}$ which is responsible for the activities of social rights associations. Although Nagib is currently disconnected from the Instituto Millenium (which appears in the network above and will be covered in more detail below). In 2009, he published an article entitled 'Towards a school that promotes the values of Millenium Institute' (Por uma escola que promova os valores do Instituto Millenium $\left.{ }^{10}\right)$. The authorship of the article has been changed to 'Comunicação Millennium'11 and today the text is no longer available on the Institute's website (Peroni et al., 2017). Miguel (2016) argues that the removal of Nagib's name from the article occurred because it is likely that the defence of a school that promotes the values of a particular institute is contradictory to the proposal of the EsP, namely, the fight against indoctrination in schools.

Miguel Nagib is married to Ruth Kicis, who appears on the EsP Facebook page as one of the team members (only she and Miguel Nagib appear as team members). We were not able to find any other information about Ruth Kicis. Beatriz Kicis, in turn, is Ruth Kicis' sister. Brait (2016) points out that Beatriz is a retired lawyer and attorney of the Federal District (DF) and a former member of the group Revoltados Online (Online Rebels). ${ }^{12}$ According to Pavarin (2017), Kicis joined the movement Online Rebels in February 2015 through Marcello Reis (who also appears on the network), having met him five months earlier during protests against the PT (Workers' Party) government in Brasilia. Pavarin (2017) points out, 
Reis was looking for someone who shared a similar ideology and technical knowledge who was willing to file an impeachment request. The conversations between the two fructified. Kicis saw in Reis a combative leadership and wrote the terms of the project.

Beatriz Kicis continues as the president of the Institute Resgata Brasil (Rescue Brazil), through which she defends the EsP agenda. The Institute aims to 'rescue the republican institutions and reestablish the cultural and family values of Brazilian ${ }^{13}$ society'. In 2018, Beatriz Kicis, who currently uses the name Bia Kicis, ran for federal deputy for the Federal District through the Progressive Republican Party (PRP), having been the third most voted federal deputy in the Federal District. ${ }^{14}$ She is one of the authors of Bill 246/2019, which is being processed by the Federal Chamber of Deputies and which establishes the programme 'Non-Partisan School' 'Escola sem Partido'. It must be noted that the EsP was not established by law, mainly because of the resistance of teachers and activists.

In addition to being the founder of the movement Online Rebels, Marcello Reis is a former pastor and was one of the main leaders of proimpeachment protest acts against former President Dilma Rousseff, who was from the Workers' Party. Reis is one of the actors who made use of social networks to gain public recognition. This can be seen in an article published by Pavarin (2017) in which he points out that 'in a given moment, his page [referring to Marcello Reis's Facebook] brought together 2 million followers on Facebook, making him one of the most popular celebrities in the "angry" category of impeachment times'. According to Pavarin, even though Online Rebels was founded in 2006 (with the original purpose 'to hunt down suspects of paedophilia') and was first remarkably visible with the protests against the government in June 2013, it was also the time when it received greater press in social networks. With the protests of 2013, Reis transformed Online Rebels into a movement of extreme right-wing political militancy in favour of military interventionism and, above all, anti-PT government (Pavarin, 2017). Marcello's greatest asset, as Pavarin (2017) points out, was to have other movements join the pro-impeachment agenda.

The recognition achieved by Reis can also be perceived through a meeting held with the former minister of education Mendonça Filho (2016), ${ }^{15}$ which was also attended by Alexandre Frota, a member of the group Online Rebels. One of the agendas of the meeting was the nonindoctrination in schools, which is admittedly one of the main ideas defended by the EsP. 
Alexandre Frota, for his part, is well known in the media for having been an actor for many years and for his involvement in several controversies. Since the pro-impeachment movements against former President Dilma Roussef of the PT, Frota has been politically very active. The then actor and now federal deputy filed an impeachment request in 2016 against the former president. That same year, he participated in several political demonstrations in favour of the impeachment. In the 2018 elections, he was elected as federal deputy for the Social Liberal Party (PSL) with 155,000 votes. On his official Facebook page, Frota defends the ideas of the EsP. It is important to point out that in court Alexandre has recently won the registration of the trademark for the Free Brazil Movement (MBL, in Portuguese: Movimento Brasil Livre). With this, we aim to show that there are disputes amongst the actors featuring in the network, which shows that it is not a totally homogeneous movement. Frota has sometimes criticised MBL as well as its representatives, but like the MBL, he also defends the EsP ideas.

MBL was set up in November 2014. According to Amaral (2015), the MBL is a trademark created by Students for Freedom (EPL, in Portuguese: Estudantes pela Liberdade) 'to participate in street demonstrations without compromising American organizations that are prevented from donating resources to political activists under the American Revenue Service (IRS) (italics ours)'. This clearly demonstrates that MBL is financed by foreign and specifically American capital, which shows that there are relationships that go beyond the network mentioned above.

In an interview with Amaral (2015), Juliano Torres, executive director of the EPL, gave the following statement, which although extensive, presents the idea that the EsP network is connected through the actors that compose it, and to institutions in other countries (as is the case with the EPL):

When the protests for the Free Pass Movement (Movimento Passe Livre) took place in 2013, several members from Students for Liberty wanted to participate, but because we receive resources from organizations like Atlas and Students for Liberty they can't perform political activities for a matter of income tax reasons in the USA. So, we said, 'Students for Liberty members can participate as individuals, but not as an organization to avoid problems.' We then decided to create a brand, it wasn't really an organization, it was just a brand for us to market ourselves in the demonstrations as the Free Brazil Movement. Then I was joined by Fábio [Ostermann] and Felipe França, who are from Recife and São Paulo, plus another four or five people, and we created the logo, the Facebook 
campaign. And then the demonstrations ended, the project ended. And we were looking for someone to take over, the page had already earned more than 10,000 likes, pamphlets. That was when we found Kim [Kataguiri] and Renan [Haas], who turned out to be an incredible turnaround with the rallies against Dilma and stuff like that. Kim is even a member of the Students for Liberty, so he was trained by that movement too. And most of the local organizers are members of the Students for Liberty. They act as members of the Free Brazil Movement, but were trained by us, in leadership courses. Kim will now participate in a philanthropic poker tournament that Students for Liberty organizes in New York City to raise funds. He will be a speaker. And he's also going to be a speaker at the international conference in February.

MBL gained great strength on the Brazilian political scene, especially through its involvement in the pro-impeachment protests against former left-wing (Workers Party) President Dilma Rousseff. Much of MBL's agenda is related to the ideas of the EsP, such as the protests organised by the group against a queer exhibition at Santander Cultural, ${ }^{16}$ in Porto Alegre, accusing it of bringing up issues related to paedophilia and zoophilia. MBL openly defends the EsP and in 2017 even organised marches across the country in its favour. ${ }^{17}$ As can be seen from Figure 1, MBL (a turquoise knot on the left side of the network), is related to several right-wing political parties through direct linkages with their politicians. This is the case of Paulo Eduardo Martins, ${ }^{18}$ federal deputy for the Brazilian Social Democracy Party (PSDB) who appears on the MBL website as one of its parliamentary representatives. Kim Kataguiri appears in the network as an important MBL figure. With other members also represented in the network, he was an organiser of the March for Freedom in 2015 which called for Rousseff's impeachment. In the 2018 elections, he was elected Federal Deputy by the Democrats (DEM), also a right-wing party.

Among the politicians who appear in the network (nodes in pink), we briefly deal with Jair Bolsonaro. In 2018, Bolsonaro was elected president of Brazil, conducting a campaign in line with the EsP agenda. In a post from 10 August 2018, the EsP Facebook page pointed out that Jair Bolsonaro was 'the only candidate running for the Presidency of the Republic to publicly commit to the approval of the EsP and the fight against gender ideology'. Throughout his campaign for the presidency, Bolsonaro defended the political ${ }^{19}$ campaigns against ideological indoctrination and gender ideology — the main agenda of the EsP. 
In the upper part of the network, it is possible to see the proximity of Jair Bolsonaro to pastors with the church Assemblies of God. Silas Malafaia is one of the church's most famous pastors, who coordinates and presents the programme 'Victory in Christ' on television and is the president of Central Gospel, one of the largest selling publishers of evangelical books and DVDs in the world. Malafaia is constantly involved in polemics against abortion and against the rights of LGBTQIA+ groups. Marco Feliciano gives public speeches replete with racism, homophobia and machismo. He was elected federal deputy by the Christian Social Party (PSC) in 2010 and in 2018 resigned to join Podemos (We Can).

Another important set of actors that appear in the network is formed by journalists and columnists (nodes in orange) and by media agencies (nodes in black). Among journalists and columnists, Rodrigo Constantino ${ }^{20}$ stands out in particular. He is an important actor in the EsP network for disseminating the ideas of the programme in different media outlets and for being linked to two high-profile institutes in Brazil. He is the president of the Liberal Institute Council and a founding member of the Millennium Institute (IMIL). Constantino has a degree in Economics, was a columnist for Veja magazine and is a columnist for important Brazilian media such as the newspapers 'Valor Econômico', 'Gazeta do Povo' and 'O Globo'. He won the Libertas Award at the XXII Forum da Liberdade (Liberty Forum) held in 2009. He has published several books such as 'Privatise now!' and 'Caviar Left'.

According to Avila (2015), it is necessary to pay attention to the Brazilian media, bearing in mind that 'most Brazilian journalistic groups have a right-wing editorial line'. Thus, the worldview that reaches the general public through the main media outlets is solely from one political perspective. As Avila (2015) points out that

[t]he 'media' does not form a monolithic group; there are left-wing vehicles, especially in the electronic media. However, the positions and interpretations of reality most displayed in the main channels of communication point out that the solutions to social problems are the reduction of the state, the reduction of taxes and the lower tax burden on companies, among others. Additionally, it is not unfounded to suggest that there is a constant attempt to denigrate left-wing policies and governments.

Some of the names mentioned by Avila (2015) in this article appear on the EsP network. Some of the names such as Luiz Felipe Pondé, Olavo de Carvalho, Reinaldo Azevedo and Rodrigo Constantino are all regarded 
as right-wing journalists. It is important to take into account that the journalists and writers who appear on the network are linked to various media outlets that are important on the Brazilian scene: news program Rede TV!, magazines Veja and Isto É, newspapers Folha de São Paulo, Gazeta do Povo, Valor Econômico, O Globo and Zero Hora. That these media agencies appear in the network does not imply that they have only right-wing journalists, but that they are important in conveying the EsP ideas as they have writers and journalists who defend and spread the agenda of this organisation.

Another important group in the network is the institutes (nodes in blue). As mentioned in the methodology section, the proliferation of these institutes is related to contemporary neoliberal ideas of governance, when non-state actors act as the state. Among these institutes we highlight the Millennium Institute and the Liberal Institute.

According to its website, the Millennium Institute (Imil) is a nonprofit organisation without party-political ties, based in Rio de Janeiro. Formed by intellectuals and businessmen, this agglomeration of think tanks promotes values and principles that promise to guarantee a free society with individual freedom, property, market and economy rights, representative democracy, rule of law and institutional limits to government ${ }^{21}$ action. Imil was founded in 2005 by economist Patrícia Carlos de Andrade under the name of Institute of National Reality (Instituto da Realidade Nacional) and was officially launched in April 2006, during the Liberty Forum in Porto Alegre.

Avila (2015) states that among Imil's sponsors are large media companies such as the RBS Group, Estadão and Abril, which demonstrates the relationship of the Institute with media outlets. Thus, it can be inferred from the network that there is a relationship between different actors around common goals, in this case, the propagation of the EsP ideas, especially those related to 'ideological indoctrination' and 'gender indoctrination'. ${ }^{22}$

The Millennium Institute is considered by Amaral (2015) as the principal think-tank of the Brazilian right wing. Prominent economistpoliticians are associated with the Institute, including the current Minister of Economy Paulo Guedes. Its sponsors are Gerdau, Editora Abril and Pottencial Seguradora, one of Salim Mattar's companies, the owner of Localiza Car Rental Company. Suzano, Bank of America, Merrill Lynch and Évora Group (owned by the Ling brothers) are also partners. William Ling participated in the founding of the Institute of Business Studies (IEE, Instituto de Estudos Empresariais) in 1984. The institute, formed 
by young business leaders, has organised the Forum since its inception. William's brother is the founder of the Liberty Institute of Rio Grande do Sul (IL, Instituto Liberdade do Rio Grande do Sul). His son, Anthony Ling, is linked to the group Students for Liberty, which created the MBL. The Ultra group's entrepreneur, Hélio Beltrão, is also among the founders of Millenium, although he has his own institute, Mises Brasil.

Through this network it is possible to see the complex interlinkages of actors and institutions that promote and defend EsP and its agenda. It is clear that contrary to what EsP states on its website, the movement does in fact have deep ideological and partisan ties with what could be broadly termed the political right-wing in Brazil. The network allows us to have a glimpse of alliances between different actors that have different characteristics, sometimes closer to neoliberal groups (as is the case of Rodrigo Constantino), other times getting closer to authoritarian populist groups (as exemplified by Silas Malafaia and Marco Feliciano).

\section{Conclusions}

As stated by several authors quoted in this article, there is a neoliberal and conservative articulation that has been built globally and that this articulation-depending on the contexts in which they are carried out and consolidated - varies ideologically according to the forces that act in each context. In some contexts, this conservative alliance takes on a more neoliberal character with a focus on transforming education into a marketable commodity. In other contexts, we have seen more conservative versions with strong neoconservative emphasis and explicit appeal to Christian/religious sentiments such as in the election of Trump in the USA and of Bolsonaro in Brazil, among other examples across the world.

Education is one of the areas where conservative positions have taken shape in recent years and, as Apple $(1996,2001)$ tells us, the right wing has been very persistent and has maintained its propositions whenever the educational crisis resurfaces more sharply. Still, corroborating some of Apple's arguments, not everything that conservatives propose is 'bad sense'-many of their arguments are based on common sense and spread a certain 'good sense'. With this play on words 'good/bad sense', Apple discusses how the conservative/neoconservative and neoliberal discourse has grown a lot because it has matured in a social fabric (depleted, broken up schools; public services without investment and bureaucratised, etc.) that favours and gives meaning to a fragile speech that sounds 
sensible and meaningful (good sense) in view of a given social context. In other words, people are not always ignorant and non-partisan when they join a conservative project — especially those of the working classes who are commonly accused of such senselessness. In some ways, the neoliberal and neoconservative proposals make sense for groups seeking change. This process of struggle for hegemony is tense, confrontational and is a result of political and social struggles for a new common sense (Hypolito \& Gandin, 2003).

In this process, opportunist groups signal with protectionist, moralistic, fair and impartial ideas they appear to be fighting for the best interests of society. The EsP is a clear example of this kind of movement. The EsP does not overtly promote a partisan agenda and therefore has appeal among all sections. However, its hidden agenda, as our network analysis here clearly reveals, is unquestionably to the contrary. The EsP is admittedly ideological and partisan, with clear international ties with agencies such as ATLAS Foundation Freedom Network, a globally influential US-based non-profit aimed at promoting free market ideologies in developing countries. EsP also has clear ties with conservative and right-wing political parties. The analysis of the EsP political network shows that it is not avowedly impartial, non-ideological or nonpartisan in character.

With regard to the survey of subjects linked to the EsP, it was possible to identify the actions of many subjects from different sectors of society. Although it is not our intention to categorise the subjects involved, we refer again to the so-called conservative modernisation in education that is the result of the successful effort of the right wing to form a broad alliance (Apple, 2001). Among its core groups, this alliance has neoliberals and neoconservatives who, despite internal contradictions, can succeed in the significant transformation of educational policy and practice.

We believe that the methodology of political governance networks used in this article with elements supported by a network ethnography, as previously mentioned, permit exploration of the multiple and complex relationships of conservative groups that helped to constitute and reinforce the EsP movement. ${ }^{23}$ Many analyses and studies can be carried out to discuss the seemingly contradictory relationships between neoliberal and conservative interests. However, our intention was to point out and analyse subjects that can be identified as part of the conservative modernisation alliance (especially, in relation to elements of the neoconservative and populist-authoritarian strand) that has greatly 
affected schools and teachers who have been mobilising to resist these retrograde initiatives and who wish to impose a censorship on the freedom of expression and teaching that has historically been built by the teachers' movement in Brazil.

\section{Declaration of Conflicting Interests}

The authors declared no potential conflicts of interest with respect to the research, authorship and/or publication of this article.

\section{Funding}

The authors disclosed receipt of the following financial support for the research, authorship and/or publication of this article: This research was funded by CNPq-National Council of Research, grant n. 438633/2016-4.

\section{Notes}

1. Hereafter EsP, following its Portuguese spelling.

2. Information retrieved April 29, 2020, from https://www.escolasempartido. org/

3. Retrieved January 8, 2020, from http://comunhao.com.br/escola-sempartido-entrevista/

4. Retrieved January 8, 2020, from http://comunhao.com.br/escola-sempartido-entrevista/

5. Retrieved December 16, 2020, from https://www.escolasempartido.org/ programa-escola-sem-partido/Acessed on

6. Free software accessible at https://gephi.org/

7. For more information on how graphs can be interpreted, see Martins (2012).

8. Non-Partisan School-Training and Improvement.

9. Non-Partisan School Association.

10. 'For a school that promotes the Millennium Institute's values'.

11. 'Millenium Communication'.

12. Right-wing group is very active in social networks. Currently, Beatriz Kicis is a Congress Representative as a member of the PSL - an extreme rightwing political party.

13. Retrieved from http://resgatabrasil.org.br/.

14. Retrieved January, 10, 2019, from https:/www.correiobraziliense.com. br/app/noticia/cidades/2018/10/15/interna_cidadesdf, $712797 /$ terceiradeputada-federal-mais-votada-bia-kicis-defende-bolsonaro.shtml

15. Retrieved January 10, 2019, from https://g1.globo.com/educacao/noticia/ ministro-da-educacao-recebe-alexandre-frota-e-lider-de-protestos.ghtml

16. The exhibition 'Queer Museum' was closed in a censorship act but justified as an administrative decision. 
17. Retrieved February 7, 2019, from https://www.gazetadopovo.com.br/ educacao/mbl-fara-marcha-pelo-escola-sem-partido-em-todo-o-pais4i3elisi28qrft1bzodr5yl11/

18. Martins is currently federal deputy of the Brazilian Social Democracy Party (PSDB).

19. Gender ideology is a particular expression which was created by Vatican to accuse any gender/sexuality discussion that defends emancipatory identity politics. In Brazil, mostly evangelic and conservative groups have assumed such expression as a political battle, accusing teachers and Workers' Party of promoting indoctrination on sexuality and gender politics in order to promote queer education.

20. Constantino published some articles defending the ideas of the EsP, especially in the newspaper Gazeta do Povo. Titles like 'Ideological Battle? No! What Exists in Brazilian Education Is Really Communist Indoctrination!', 'The Pluralism of the Non-Partisan School Project' and 'School Without a State Is Better Than Non-Partisan School: Is It Really?' can be found online. Retrieved January 23, 2019, from https://www.gazetadopovo.com.br/ rodrigo-constantino/tag/escola-sem-partido/

21. Information retrieved February 5,2019, from https://www.institutomillenium. org.br/institucional/quem-somos/

22. See footnote 19 .

23. As we concluded the drafting of this text, the Federal Supreme Court (STF) paved the way for the EsP's intentions as a legal claim to create laws in states and municipalities to impose its ideology, which left these groups very unhappy, defeated, but still threatening to take law into their own hands, whatever it may mean. In any case, it was a victory for teachers, for schools and for all those who fight for democracy.

24. As we concluded the drafting of this text, the Federal Supreme Court (STF) paved the way for the EsP's intentions as a legal claim to create laws in states and municipalities to impose its ideology, which left these groups very unhappy, defeated, but still threatening to take law into their own hands, whatever it may mean. In any case, it was a victory for teachers, for schools and for all those who fight for democracy.

\section{ORCID iDs}

Álvaro Moreira Hypolito iD https://orcid.org/0000-0003-1487-0413

Iana Gomes de Lima iD https://orcid.org/0000-0002-6386-7248

\section{References}

Afonso, A. J. (1998). Políticas educativas e avaliação educacional: para uma análise sociológica da reforma educativa em Portugal (1985-1995) [Educational policies and educational assessment: Towards a sociological analysis of educational reform in Portugal (1985-1995)]. IEP/CEEP/ Universidade do Minho. 
Amaral, M. (2015). A nova roupagem da Direita [The new dress of the right]. Agência Pública. Retrieved September 19, 2018, from https://apublica. org/2015/06/a-nova-roupa-da-direita/

Apple, M. W. (1996). Cultural politics and education. Teachers College Press.

Apple, M. W. (2001). Educating the 'right' way: Markets, standards, god and inequality. Routledge/Falmer.

Avila, R. I. (2015). Por que os veículos de comunicação têm viés editorial de direita? [Why do the media have a right-wing editorial bias?]. Brasil Debate. Retrieved from http://brasildebate.com.br/por-que-os-veiculos-decomunicacao-tem - vies-editorial-de-direita/\#sthash.08FZhFsy.dpuf

Ball, S. J. (2008). New philanthropy, new networks and new governance in education. Political Studies, 56(4), 747-765. https://doi.org/10.1111/j.14679248.2008.00722.x

Ball, S. J. (2009). Privatising education, privatising education policy, privatising educational research: Network governance and the 'competition state'. Journal of Education Policy, 24(1), 83-99. https://doi. org/10.1080/02680930802419474

Ball, S. J. (2011). New states, new governance and new education policy. In M. W. Apple, S. J. Ball, \& L. A. Gandin (Eds.), The Routledge international handbook of the sociology of education (pp. 155-166). Routledge.

Ball, S. J. (2012). Global Education Inc.: New policy networks and the neoliberal imaginary. Routledge.

Ball, S. J. (2016). Following policy: Networks, network ethnography and education policy mobilities. Journal of Educational Policy, 31(5), 1-18. https:// doi.org/10.1080/02680939.2015.1122232

Ball, S. J., \& Thawer, S. (2018). Nodes, pipelines, and policy mobility: The assembling of an education shadow state in India. In K. J. Saltman \& A. J. Means (Orgs.), The Wiley handbook of global educational reform (pp. 71-86). Wiley Blackwell.

Bordoli, E., \& Conde, S. (2020). The conservative education project in Uruguay at the beginning of the 21 st century: Privatizing progress and ministerial protection [El proyecto educativo conservador en Uruguay en los albores del siglo XXI: avance privatizador y tutela ministerial]. Práxis Educativa, $15,1-21$.

Brait, D. (2016). The protagonists of the Non-Partisan school. In educational action [Os Protagonistas do EsP. In A ideologia do movimento Escola Sem Partido: 20 autores desmontam o discurso (pp. 161-165). Ação Educativa.

Clarke, J., \& Newman, J. (1997). The managerial state: Power, politics and ideology in the remaking of social welfare. SAGE Publications.

Casimiro, Flávio H. C. (2018). The New Right: Apparatus of political and ideological action in contemporary Brazil. [Nova Direita: aparelhos de ação política e ideológica no Brasil contemporâneo]. Expressão Popular: São Paulo. 
Dale, R. (2000). Globalization and education: Demonstrating 'common world educational culture' or locating a 'Globally structured educational agenda'? Educational Theory. 50(4), 427-448.

Dale, R. (2005). Globalisation, knowledge economy and comparative education. Comparative Education, 41(2), 117-149. https://doi. org/10.1080/03050060500150906

Hall, S. (2009). Da diáspora: Identidades e mediações culturais [From the diaspora: cultural identities and mediations]. Editora UFMG.

Howard, P. N. (2002). Network ethnography and the hypermedia organization: New media, new organizations, new methods. New Media Society, 4, 550574. https://doi.org/10.1177\%2F146144402321466813

Hypolito, A. M., \& Gandin, L. A. (Orgs.). (2003). Educação em tempos de incertezas [Education in uncertain times] (2nd ed.). Autêntica Editora.

Lacerda, M. B (2019). O novo conservadorismo brasileiro: de Reagan a Bolsonaro [The new Brazilian conservatism: from Reagan to Bolsonaro]. Zouk.

Löwy, M. (2015). Conservadorismo e extrema-direita na Europa e no Brasil. Serviço Social e Sociedade [Conservatism and the extreme right in Europe and Brazil] (São Paulo, n. 124, p. 652-664, out./dez.).

Martins, D. L. (2012). Análise de redes sociais de colaboração científica no ambiente de uma federação de bibliotecas digitais [Analysis of scientific collaboration social networks in the environment of a federation of digital libraries]. (Tese Doutorado), Universidade de São Paulo.

Miguel, L. F. (2016). Da 'doutrinação marxista' à 'ideologia de gênero': Escola sem Partido e as leis da mordaça no parlamento brasileiro [From 'Marxist indoctrination' to 'gender ideology': Non-Partisan School and the gag laws in the Brazilian parliament]. Direito e Práxis, 7(15), 590-621. https://doi. org/10.12957/dep.2016.25163

Moll, R. (2010). Reaganetion: a nação e o nacionalismo (neo)conservador nos Estados Unidos (1981-1988) [Reaganetion: The nation and (neo)conservative nationalism in the United States (1981-1988)]. Dissertação (Mestrado em História) - Programa de Pós-Graduação História, Universidade Federal Fluminense.

Moll, R. (2015). Imaginando o 'outro' e a nação nas relações internacionais: commentary magazine, the New Republic e o intervencionismo dos Estados Unidos na Nicarágua e El Salvador (1977-1992) [Imagining the 'other' and the nation in international relations: commentary magazine, the New Republic and US interventionism in Nicaragua and El Salvador (1977-1992)]. Tese (Doutorado em Relações Internacionais)—Programa San Tiago Dantas de Pós-Graduação em Relações Internacionais, UNESP/ UNICAMP/PUC-SP.

Nambissan, G., \& Ball, S. J. (2010). Advocacy networks, choice and private schooling of the poor in India. Global Networks, 10(3) 324-343. 
Pavarin, G. (2017). Ostracism of the biggest revolt online [O ostracismo do maior revoltado online]. Piaui/Folha, 26 maio. Retrieved September 19, 2018, from https://piaui.folha.uol.com.br/o-ostracismo-do-maior-revoltadoonline/

Penna, F. (2017). The Non-Partisan School as a key to reading the educational phenomenon. [O Escola sem Partido como chave de leitura do fenômeno educacional. In: Frigotto, G. (ed.) "Non"-Partisan School: sphinx that threatens education and Brazilian society [Escola "sem" partido: esfinge que ameaça a educação e a sociedade brasileira] (pp. 35-348).

Peroni, V., Caetano, M. R., \& Lima, P. (2017). Today's educational reforms: The implications for democracy [Reformas educacionais de hoje: As implicações para a democracia]. Retratos da Escola, 11(21), 415-432. https://doi.org/10.22420/rde.v11i21.793

Schirmer, E. B., \& Apple, M. W. (2016). Teachers, school boards, and the power of money: How the right wins at the local level. The Educational Forum, 80(2), 137-153.

Severo, R. G., \& Estrada, R. D. (2019). Interview with Michael Apple [Entrevista com Michael Apple]. Educação em Revista, 35, 1-14.

Silveira, S. A. (2015). Right on social media online [Direita nas redes sociais online]. In S. Velasco e Cruz, A. Kaysel, \& G. Codas (Orgs.), Right, go back! The return of the right and the Brazilian political cycle [Direita, volver!: o retorno da direita e o ciclo político brasileiro] (pp. 213-230). Editora Fundação Perseu Abramo. 